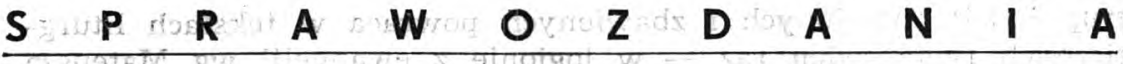

\section{SPRAWOZDANIE Z DZIALALNOŚCI POLSKIEGO TOWARZYSTWA TEOLOGICZNEGO W KRAKOWIE W ROKU 1979}

W roku 1979 Polskim Towarzystwem Teologicznym w Krakowie kierował zarząd wybrany na. Walnym Zebraniu w dniu 9 lutego $1979 \mathrm{r}$. w składzie: ks. doc. dr hab. Jerzy Chmiel (prezes), o. dr Jan W ichrowicz OP (wiceprezes), ks. dr Stanisław Męd al a CM (sekretarz), ks. lic. Mieczysław $\mathrm{P}$ i a t SDB (skarbnik) i ks. mgr Władysław Włodarski (bibliotekarz) - dokooptowany przez Zarząd na mocy art. 18 Statutu w dniu 23 lutego 1979 r. Do Komisji Rewizyjnej weszli: ks. prał. Czesław Obtułowicz (przewodniczacy) oraz ks. dr Stefan Ryłko CRL i ks. lic. Antoni Okrzesik (członkowie).

Zarząd PTT w Krakowie odbył cztery przepisane przez Statut zebrania, na których omówiono: zalecenia Komisji Rewizyjnej, uchwałę Rady Państwa PRL z dnia 12 maja 1979 r. o popieraniu rozwoju terenowych towarzystw naukowych oraz sprawozdanie $\mathrm{z}$ kontroli państwowej Towarzystwa. Kontrola państwowa Towarzystwa przeprowadzona w dniach 8-12 listopada 1979 r. przez Wydzial Spraw Społeczno-Administracyjnych Urzędu Miasta Krakowa wykazała prawidłowość działania PTT w Krakowie $\mathrm{z}$ punktu widzenia prawnego. Towarzystwo prowadziło w myśl Statutu działalność odczytową na zebraniach plenarnych i sekcyjnych oraz działalność wydawniczą.

\section{I}

W okresie sprawozdawczym odbyło się 6 zebrań ogólnych z następującymi referatami: ks. dr hab. Jan Sieg TJ, Ruch katolickiej odnowy chrześcijańskiej (15 II 1979); ks. doc. dr hab. Jerzy Chmiel, Całun Turyński - problem teologiczny (15 III 1979); prof. dr hab. Marian Plezia, Sw. Stanisław a błog. Bogumit (17 V 1979); ks. doc. dr hab. Jerzy Chmiel, Apostolstwo biblijne $i$ jego miejsce we wspótczesnym duszpasterstwie (20 IX 1979); dr med. Wanda Półtawska, Na pograniczu życia i śmierci; obserwacje medyczne (18 X 1979); ks. prof. dr hab. Ignacy $\mathrm{R}$ óż y k i, Najaktualniejsze zagadnienia eschatologiczne (w związku z listem Kongregacji dla Doktryny Wiary) (15 XI 1979).

Zebrania organizowane były przy wydatnej pomocy Wydziału Duszpasterskiego Kurii Metropolitalnej w Krakowie, który rozpisywał zaproszenia. Miejscem zebrań ogólnych był palac Arcybiskupów Krakowskich przy ul. Franciszkańskiej 3.

W dniu 26 kwietnia 1979 r. we współpracy z Papieskim Wydziałem Teologicznym w Krakowie urządzono sesję naukową poświęconą encyklice papieża Jana Pawła II ,Redemptor hominis" z następującymi referatami: ks. prof. dr hab. Marian Jaworski, Kategorie językowe encykliki; ks. doc. dr hab. Jerzy Chmiel, Biblijne podstawy encykliki; ks. doc. dr hab. Tadeusz Pieronek, Problem praw czlowieka w encyklice; ks. dr Jan Szkodoń, Udziat w potrójnej funkcji Chrystusa wedtug encykliki; ks. dr Stanisław N owak, Srodki odnowy Kościoła wedtug encykliki. 
Ponadto Towarzystwo zorganizowało dwie serie odczytów w kościele św. Mikołaja w Krakowie. Pierwsza seria była na temat: Męka Pańska $w$ świetle wspótczesnej teologii i obejmowala 4 konferencje: o. prof. dr hab. Augustyn Jankowski OSB, Szczególne aspekty Męki Pańskiej wedtug św. Jana (8 III 1979); ks. dr Stanisław M ę dala CM, Chronologia Męki Pańskiej w świetle dokumentów z Qumran (9 III 1979): ks. dr Stanisław Now ak, Duchowość pasyjna (10 III 1979); ks. doc. dr hab. Jerzy Chmiel, Całun Turynski świadkiem Męki i Zmartwychwstania (11 III 1979). Druga seria była poświęcona tematowi: Wierzę $w$ życie wieczne, na który to temat ks. doc. dr hab. Jerzy $\mathrm{Chmiel}$ wygłosif 3 konferencje: Wiara $w$ życie pozagrobowe $w$ historii ludzkości (14 XI 1979), Zmartwychwstanie umartych (21 XI 1979) i Oczekujemy przyjścia Pana naszego Jezusa Chrystusa (28 XI 1979).

W ramach PTT działa 10 sekcji naukowych i 1 sekcja wydawnicza. $\mathrm{Na}$ zebraniach sekcyjnych, wygłoszono łącznie 71 referatów.

Sekcja filoz oficzna, kierowana przez ks. prof. dra hab. Tadeusza Wojciechowskiego, odbyła cztery zebrania $\mathrm{z}$ następującymi referatami: ks. doc. dr hab. Romuald $\mathrm{Rak}$, Teologia pastoralna a misterium śmierci (30 III 1979); ks. prof. dr hab. Tadeusz W ojciechowski, $Z$ problematyki manipulacji mózgiem ludzkim (22 V 1979); ks. dr Józef Ż y iński, Metodologiczne aspekty badań nad śmiercia $w$ USA (6 XI 1979); ks. dr Józef Z y ciński, Wptywy Wschodu na wspótczesna myśl amerykańska (4 XII 1979). Zebrania odbywaly się w sali Krakowskiego Seminarium Duchownego przy ul. Manifestu. Lipcowego 4.

Sekcja biblijno-1iturgiczna, której kierownikiem jest ks. doc. dr hab. Jerzy Chmiel, pracowała w dwóch odrębnych grupach: biblijnej i liturgicznej. Razem było 9 posiedzeń naukowych z 14 referatami i komunikatami o następującej tematyce: ks. doc. dr hab. Jerzy Chmiel, Historia $i$ hermeneutyka $w$ J 20, 1-10 (7 III 1979); prof. dr Ludger Schenke (Moguncja), Problem literacki w J 6, 26-58 (23 III $1979-$ wykład gościnny w j. niem.): ks. prof. dr Walter Gross (Moguncja), Fatszywy prorok i niepostuszny maż Boży $w \quad 1$ Krl 13 (23 III 1979 wykład gościnny w j. niem.); o. prof. dr Georg Braulik OSB (Wiedeń), Bliskość Boga a sprawiedliwość społeczna. Rozumienie prawa deuteronomistycznego $w$ okresie niewoli (26 IV 1979 - odczyt gościnny w j. niem.); ks. dr Tomasz Jelo nek, Łukasz autorem Listu do Hebrajczyków? oraz komunikat o. prof. dra hab. Augustyna Jankowskiego OSB z posiedzenia Papieskiej Komisji Biblijnej w Rzymie (16 V 1979); ks. dr Stanisław Włodarczyk, Język Biblii - język Boga jako wzór języka w poszukiwaniu prawd wiary $(24 \mathrm{X}$ 1979). W dniu 22 listopada $1979 \mathrm{r}$. sekcja biblijno-liturgiczna zorganizowała sesję naukową w 10-tą rocznicę śmierci śp. ks. prof. dra Aleksego Klawka z referatami: ks. prof. dr hab. Stanisław Grzybek, Propagator ruchu biblijnego; prof. dr hab. Tadeusz Le wicki, Z dziejów orientalistyki lwowskiej; doc. dr hab. Andrzej Z aborski, Ks. Aleksy Klawek jako tłumacz; ks. doc. dr hab. Jerzy Chmiel, Badania onomastyczne $w$ egzegezie biblijnej. W grupie liturgicznej wygłoszono referaty: o. dr Franciszek M a ła c z yn sk i OSB, Problemy przekładu ksiag liturgicznych $i$ wydania nowego mszatu polskiego (17 I 1979); ks. dr Józef S roka, Wkład „Mysterium Christi” $w$ polski ruch liturgiczny (14 II 1979); ks. dr Stefan " Ci chy, Instrukcja Kongregacji na temat liturgicznego wychowania alumnów $w$ seminariach (5 XII 1979). Miejscem zebrań była sala Krakowskiego Seminarium Duchownego przy ul. Podzamcze 8.

Sekcja apologetyczno-religioznawcza, którą kieruje ks. doc. dr hab. Adam $K \mathrm{ubiś}$, odbyła 1 zebranie $\mathrm{z}$ referatem prof. dra hab. M. Bartla, W kręgu ruchu ekumenicznego $w$ Anglii (14 XII 1979). 
Sekcja dogmatyczno-mora Ina, pod kierunkiem o. dra Jana Wi chrowicza OP, w roku sprawozdawezym miała 7 zebrań z następującymi referatami: ks. dr Jan $\mathrm{K}$ owalski, Wspomnienie o $k s$. prof. drze Wtadystawie Wichrze. W 10-ta rocznice śmierci (8 I 1979); o. dr Otto $\mathrm{F}$ il e $\mathrm{k}$ OCD, Poszukiwania nowych form moditiwy w duchowości Wschodu (5 II 1979): o. dr Salezy Ka fel OFMCap, Miłość matżeńska wedtug Piusa XI $i$ Pawła VI (5 III 1979): o. dr Marian Piotr L is o w s k i OFMConv, Chrześcijańska asceza a człowiek wspótczesny (2 IV 1979); o. dr Jan W ichrowicz OP, Wymagania moralne zawarte $w$ encyklice, ,Odkupiciel człowieka" (8 X 1979); ks. dr Jan Hojnow ki SCJ, Niektóre zagrożenia dla egzystencji narodu polskiego w chwili obecnej (5 XI 1979).i ks. prof. dr hab. Tadeusz SI p k o TJ, Ideologiczne uwarunkowania zagrożenia człowieka $w$ cywilizacji współczesnej (4 XII 1979). Posiedzenia sekcji miały miejsce w sali Kolegium OO. Dominikanów przy ul. Stolarskiej 12.

Sekcja history c zna, prowadzona przez ks. dra hab. Jana $\mathrm{Kusia}$, odbyła 4 zebrania $\mathrm{z}$ następującymi referatami: ks. prof. dr Ludwik P i e c h$\mathrm{n}$ ik TJ, Akademia Wileńska w pierwszej połowie XVIII wieku (20 III 1979); ks. dr Stefan Ryłko CRL, Z historii kultu św. Józefa na Kazimierzu (9 XI 1979); ks. prof. dr hab. Wladysław Smereka, Zasiugi śp. $k s$. prof. Aleksego Klawka dla rozwoju teologii w Polsce (14 XI 1979) i ks. dr Stefan R yłko CRL, Wyrazy kultu św. Józefa w diecezjach polskich (26 XI 1979). Zebrania sekcji odbywały się w sali Krakowskiego Seminarium Duchownego przy ul. Podzamcze 8.

Sekcja praw a kan onicznego, której przewodniczy ks. doc. dr hab. Tadeusz Pieronek, zorganizowała w dniu 26 lutego 1979 r. ogólnopolskie sympozjum nt. Papiestwo we wspólnocie Kościoła z udziałem J. Em. Ks. Kard. Macharskiego i 41 uczestników z całej Polski. Na sympozjum wygłoszono 4 referaty: ks. prof. $d r$ hab. Marian ż u rowski (ATK - Warszawa), Rola Biskupa Rzymu we wspólnocie Kościoła; ks. doc. dr hab. Edward Szt afrowski (ATK - Warszawa), Papież a Kolegium Biskupów; ks. doc. dr hab. Józef. Krukowski (KUL), Ochrona praw człowieka $w$ posoborowych dokumentach papieskich; ks. doc. dr hab. Tadeusz Pieronek, Stużba dla Kościota powszechnego poprzez Kościót partykularny $w$ nauce Jana Pawta II. Ponadto w dniu 24 listopada $1979 \mathrm{r}$. odbyło się zebranie sekcji $z$ referatem ks. doc. dra hab. Tadeusza P i eronka, Problem ochrony praw catowieka $w$ encyklice Jana Pawta If „Redemptor hominis" oraz w wystapieniu Papieża na forum ONZ. Sesja i zebranie miały miejsce w pałacu Arcybiskupów Krakowskich przy ul. Franciszkańskiej 3 .

Sekcja mis jologic zn a, której kierownikiem jest ks. dr hab. Antoni B a ciński CM, odbyła cztery zebrania $\mathrm{z}$ następującymi referatami: ks. dr hab. Jan Sieg TJ, Działalność misjonarza a sprawa rozwoju społeczno-gospodarczego (28 III 1979); ks. Ignacy P I u z c z y k OMI, Z pracy Ojców Oblatów na Cejlonie (20 V 1979): dr Wanda M a lcze w s a, $Z$ mojej pracy lekarskiej $w$ szpitalu misyjnym $w$ Ugandzie (24 X 1979) i ks. Augustyn Hamiele c SiM, Dziełalność misyjna Księży Misjonarzy Saletynów (28 XI 1979). Zebrania, często ilustrowane przeźroczami, miały miejsce w sali Krakowskiego Seminarium Duchownego przy ul. Podzamcze 3.

Sekcja pastoralno-homiletyczna w Kalwarii Zebrzydowskiej, którą prowadzi o. dr Wiesław M u r aw i e c OFMBern, ma na swoim koncie 3 zebrania $\mathrm{z}$ referatami: $\mathrm{ks}$. dr Fanciszek $\mathrm{Br}$ a ch a CM, Wybrane zagadnienia kultu św. Józefa (10 V 1979); o. lic. Daniel Z $\mathrm{Z}$ ó 1 k ow sk i OFMBern, $Z$ zagadnień parapsychologii (22 IX 1979) i o. mgr Bogumił Migdal OFMBern, Bernardyńsey kapelani wojskowi podczas II wojny światowej (8 XI 1979). Zebrania odbywaly się w Wyższym Seminarium Duchownym 00 . Bernardynów w Kalwarii Zebrzydowskiej. 
Sekcja-oddzial w Tarnowie, na czele której stoi ks. dr Adam Nowak, miała 5 posiedzeń z następujacymi referatami: ks. dr Pawel Sliw a, Kryterium umitowania prawdy (16 I 1979); ks. bp dr Jerzy Ablewicz, Teologiczne $i$ duszpasterskie problemy dzisiejszej Afryki (14 III 1979); ks. dr Stanisław Langosz, Prawa dziecka w nauce św. Bazylego (12 X 1979): ks. dr hab. Jan Dudziak, Praktyka kanonizacyjna świętych przed Dekretami papieża Grzegorza IX (23 XI 1979) i ks. dr hab. Wojciech Kania, Nauka o Matce Boskiej w pismach św. Bazylego (8 XII 1979). Ponadto czlonkowie sekcji odbyli dwa zebrania organizacyjne w zwiąku z przygotowaniem do druku VII tomu, ,Tarnowskich Studiów Teologicznych".

Sekcja w Tuchowie, prowadzona przez ks. mgra Andrzeja Rębacza CSsR, zapisala w kronikach 10 zebrań z referatami: o. dr Jan W o jnowski, Problematyka życia i dzialalności św. Stanislawa Bisłıupa (9 I 1979); o. dr Jan Wojnowski, Problematyka śmierci i kultu św. Stanistawa Biskupa (13 II 1979); o. lic. Andrzej Wielgus, Zmartwychwstanie Jezusa jako fakt historyczny (13 III 1979); o. lic. Jan Chaim, Rola sakramentów Eucharystii $i$ Pokuty $w$ dziele usprawiedliwienia (24 IV 1979): o. dr Antoni Bazielich, Dary Ducha Swiętego w nauce Ojców Koścrioła i katolickiej myśli teologicznej (18 V 1979); o. doc. dr hab. Edmund Murawiec, Przedmiot i zadania filozofii chrześcijańskiej"(9 X 1979); o. dr Jan Wojnowski, Założyciele monachizmu egipskiego (13 XI 1979); o. dr Antoni Bazielich, Geneza życia zakonnego (25 XI 1979); o. lic. Jan Chaim, Zarys problematyki Kongresu Mariologicznego i Maryjnego $w$ Saragosie $w$ dniach 3-12 X 1979 r. (4 X 1979) i o. dr Jan Wojnowski, Epigoni i syntetycy monachizmu egipskiego (11 XII 1979). Posiedzenia odbywały się w Wyższym Seminarium Duchownym OO. Redemptorystów w Tuchowie.

\section{III}

Sekcja W y dawnicza PTT w Krakowie, którą kieruje ks. prof. dr hab. Stanisław Grzy bek, w roku sprawozdawczym wydała: 6 numerów dwumiesięcznika Ruch Biblijny i Liturgiczny w nakładzie 3200 egzemplarzy każdy; numer specjalny Ruchu Biblijnego i Liturgicznego poświẹcony papieżowi Janowi Pawłowi II z racji Jego pielgrzymki do Polski (2-10. VI 1979) w dwóch wydaniach (I wyd. - 10.000 egz.: II wyd. - 8.000 egz.); Analecta Cracoviznsia t. IX (1977) i t. X (1978); ks. Kłósak Kazimierz, $\mathrm{Z}$ zagadnień filozoficznego poznania Boga; ks. Przy by s e ws ki Bolesiaw, Romańskie kościoty pielgrzymkowe; ks. bp Pietraszko Jan, Po śladach Stowa Bożego; ks. bp Mały siak Albin, Z duszpasterskiej teki; Praca zbiorowa, Specjalistyczne aspekty problemu przerywania ciázy.

\section{IV}

W dniu 31 XII 1979 r. liczba czlonków Polskiego Towarzystwa Teologicznego w Krakowie wynosiła 282; w tym 250 członków zwyczajnych i 32 wspierających. W roku sprawozdawczym przyjęto 13 czionków zwyczajnych, a skreślono $z$ listy 8 członków zwyczajnych. W ostatnim rokn Bóg powolał do siebie dwóch członków zwyczajnych Towarzystwa: ks. prał. dra Stanisława Dąbrowskiego i ks. prał. Józefa Majgiera. Nazwiska obydwóch zmarłych członków uchwała Zarządu PTT postanowiono wpisać do Księgi Członków Zasỉużonych dla Towarzystwa. 